\title{
The Digital Publishing Communications Circuit
}

Padmini Ray Murray and Claire Squires

Stirling Centre for International Publishing and Communication

Division of Literature and Languages

Pathfoot Building

University of Stirling

Stirling FK9 4LA

padmini.raymurray@stir.ac.uk; claire.squires@stir.ac.uk

\section{Biographies}

Padmini Ray Murray lectures in Publishing Studies at the University of Stirling. Her current research projects include an AHRC-funded project entitled 'Meghdoot: Using New Technologies to Tell Age-Old Stories' about making video-games in India, and the NESTA/AHRC/Creative Scotland-funded CReATeS (Consortium for Research into Arts and Technology in Scotland http://creates.stir.ac.uk/ ). She has published on digital technologies and their impact on graphic novels, the poetry of Byron, and has contributed to The Edinburgh History of the Book in Scotland, Volume 3, 1800-1880 and the forthcoming history of Oxford University Press. Her industry experience includes Seagull Books, Canongate Books, Ottakars Books and Edinburgh University Press. She is on the Advisory Board of Graphic Scotland and in charge of research and development at the Electric Bookshop.

Claire Squires is Professor of Publishing Studies and Director of the Stirling Centre for International Publishing and Communication at the University of Stirling. Her publications include Marketing Literature: the Making of Contemporary Writing in Britain and Philip Pullman: Master Storyteller, and she is co-Volume editor of the forthcoming Cambridge History of the Book in Britain Volume 7: The Twentieth Century and Beyond. Her research includes the AHRC Digital Transformations R\&D project 'The Book Unbound: Disruption and Disintermediation in the Digital Age' (www.bookunbound.stir.ac.uk), the RSE-funded Book Cultures, Book Events (http://www.bookcultures.stir.ac.uk/), and the NESTA/AHRC/Creative Scotland-funded CReATeS (Consortium for Research into Arts and Technology in Scotland http://creates.stir.ac.uk/ ). She is a judge for the Saltire Society Literary and Publisher of the Year Awards. She previously worked at Hodder Headline publishers in London. 


\author{
Keywords \\ digital publishing \\ publishing \\ Darnton \\ communications circuit \\ authorship \\ reading
}

\begin{abstract}
The publishing value chain has remained relatively consistent since the invention of the printing press. Robert Darnton's influential model of the communications circuit of the book, which tracks how intellectual property circulated in $18^{\text {th }}$ century France, has been a largely accurate representation of the publishing industry until the late $20^{\text {th }}$ century. This article examines changes to the publishing industry, particularly as a result of the disruptions and disintermediations of the digital age, and proposes a re-drawing of the communications circuit for the $21^{\text {st }}$ century. The research in this article was supported by the Arts and Humanities Research Council grant number AH/J01317X/1 The Book Unbound: Disruption and Disintermediation in the Digital Age.
\end{abstract}

\title{
Table of Figures
}

- Figure 1: Adapted from Darnton's Communications Circuit.

- Figure 2: Revised communications circuit: Late 20th century print publishing communications circuit.

- Figure 3: Self-Publishing Communications Circuit.

- Figure 4: Digital Publishing Communications Circuit.

- Figure 5: Readers in the Digital Publishing Communications Circuit.

The publishing value chain has remained relatively consistent since the invention of the printing press, and Robert Darnton's influential model of the communications circuit of the book, which tracks how intellectual property circulated in 18th century France, has been a largely accurate representation of the publishing industry until the late 20th (Figure 1) (Darnton 1990). The human experience of how we produce, disseminate and perceive text is 
now, however, being irrevocably transformed by digital technologies. The traditional value chain, which traces the trajectory of intellectual property from author to reader, and where publishing activities such as editorial, marketing and design are all performed by the single entity of the publisher, is being disrupted and disintermediated at every stage. Though Darnton's communications circuit does not posit a hierarchy as such, authority is reinforced by the flow of different modes of capital (economic, social and cultural).

[Insert Figure 1: Adapted from Darnton's Communications Circuit.]

These seismic shifts from print and paper to digital ink and screen have resulted in new business models that challenge the prevailing hierarchies of cultural gatekeeping, and have also reshaped perceptions of the book as cultural artefact. Authors can now publish, market and distribute their work without the aid of a publisher, and the relationships between readers and other agents are being mediated in new ways. The conflation of roles (such as those of the author and publisher), increasing redundancy of other roles (such as the printer), and consequences such as readers becoming content-creators, all contribute to a new publishing ecosystem, which calls for a re-examination of the model advanced by Darnton. Drawing both on broader industry developments and a series of case studies of small- to mid-sized UK-based independent publishing companies (And Other Stories, Blasted Heath, Canongate, Faber \& Faber, Guardian Books), this article establishes an emerging digital publishing communications circuit.

\section{Authors}

[Insert Figure 2: Revised communications circuit: Late 20th century print publishing communications circuit.]

Our first revision of Darnton's communications circuit (Figure 2) adds a new intermediary: that of the literary agent. The rise of the literary agent in Anglo-American publishing had its beginnings in the 19th century, with the early agents A P Watt and J B Pinker inserting themselves between the author and the publisher, acting as business managers but also as promoters and patrons (Gillies 2007). As the publishing industry conglomerated and became more intensely focused on profit in the late $20^{\text {th }}$ century, literary agents sought to maximize profit by negotiating higher advances and royalty deals for their clients (Squires 2007, Thompson 2010). Andrew Wylie achieved notoriety by aggressively seeking a very high deal for his client Martin Amis in the 1990s (Amis 2000, Wilson 1995, Moran 2000). His role is much more sympathetically drawn by Salman Rushdie as both friend and passionate protector under the life-endangering conditions of the Fatwa (Rushdie 2012).

The role of the 'author-promoter', arising towards the end of the $20^{\text {th }}$ century under marketoriented, conglomerate publishers, marketing their work via the media and engaged with 
reader via meet-the-author events in bookshops and at literary festivals (Gardiner 2000, Squires 2007), is amplified by the advent of digital technologies in the $21^{\text {st }}$. Social media such as Facebook and Twitter allow authors to communicate directly and immediately with their readers, solidifying the dotted line drawn from reader to author in the communications circuit. Leading literary novelists such as Salman Rushdie and Margaret Atwood have very sizeable followings on Twitter, for example (c.600,000 and c.400,000 respectively), with the latter commenting on how she uses it not solely to discuss and promote her writing, but also to develop a community around a set of literary, political, and other interests (Rushdie 2013, Atwood 2013, Atwood 2010).

[Insert Figure 3: Self-Publishing Communications Circuit.]

The digital technologies of the 21st century have made another significant disruption in the communications circuit, as Figure 3 illustrates. Self-publishing is by no means new, but digital technologies - and new business models based upon them - have offered opportunities for authors to do without traditional publishers. The rise of desk-top publishing software in the 1980s, with programmes such as Pagemaker, Quark Express and InDesign, meant that authors were able to prepare their own manuscripts for publication, and barriers to entry to the industry for kitchen-table start-up publishers were lowered (Alpert 1987). The development of digital publishing via ebooks, along with platforms provided by retailers and distributors for their sale and delivery, has increased exponentially the possibilities for publishing without a publisher. Thus, authors form business relationships directly with retailers and distributors including Amazon, Barnes \& Noble and Kobo, via their authorpublishing programmes Kindle Direct, PubIt! and Writing Life. The promotional animation for Amazon's Kindle Direct programme indicates very clearly the disruption in the publishing process. The struggling cartoon author at his computer is inspired to publish direct with Amazon, enticed with promises to 'Keep control', 'Distribute globally', 'Get to market fast' (with publishing taking 'less than 5 minutes', and the book appearing on Amazon 'within 24 hours') and, crucially, to 'Earn 70\% royalty' (Amazon 2013).

The relationships drawn in the self-publishing communications circuit thus disintermediate Darnton and the late $20^{\text {th }}$ century versions. Literary agents disappear, as do publishers, with a line instead being drawn directly from the author to the retailer and distributor. Nonetheless, there are a range of ways in which self-published authors buy in publishing services, including editorial, design, marketing, publicity and sales, as well as digital services such as conversion and media content production, and are guided by advice on self-publishing often, ironically, produced as books by conventional publishers (e.g. Baverstock 2011, Rich 2006). 
There are notable examples of authors who, from a digital self-publishing base, have achieved extremely high sales, including John Locke, who published his own account of How I Sold One Million Ebooks in Five Months (Locke 2011) - and Amanda Hocking. Hocking's phenomenal success as a self-publisher from 2010 onwards led to large publishing deals with conventional publishers to publish a series of her books from early 2012, making her a hybrid self- and conventionally-published author (Pilkington 2012). Hocking's turn to the traditional model of 'legacy' publishing came about not just through the lure of a large advance, but through the pressures of sustaining a full publishing service herself: 'dealing with technical glitches on Kindle, creating her own book covers, editing her own copy, writing a blog, going on Twitter and Facebook to spread the word, responding to emails and tweets from her army of readers'. She was 'burned out by the stress of solo publishing'. For Hocking, the activities traditionally undertaken by a publisher became impossible to sustain without a very coordinated provision of freelancers and outsource agencies (Pilkington 2012).

A survey conducted in 2012 with over 1000 self-published authors demonstrated a stratification of earnings and activities, with $10 \%$ of authors earning $75 \%$ of royalties. Selfpublished authors frequently seek help with publishing their book, with a reported $41 \%$ paying for a cover designer, and $29 \%$ for copy-editing. Overall, seeking help (paid or unpaid) for aspects of publishing (copy-editing, proof-reading and design) correlated with increased earnings, with such writers earning $34 \%$ more than average (Cornford \& Lewis 2012). Allan Guthrie of digital crime publisher Blasted Heath commented that within the digital publishing environment:

you don't need a publisher, [but] you do need some kind of publishing services, which $[\ldots]$ amounts to the same thing in a way. So, either you [...] do them yourself and hire people to do it and run a business and spend a lot of time and effort [...], or you can get a publisher to do it. And that's where a publisher will add value [...] saving you the time so you can write because for most writers that's pretty important, especially because most writers have full time jobs [...] time is a really precious commodity. (Guthrie \& MacRae 2012)

The motivation for starting Blasted Heath came from one of its founders identifying 'a state of transformation or turmoil' in publishing, in which authors were finding 'the onus was much more on them to create their own brands, promote themselves, to, ultimately, sell their own books'. This was an approach informed by social media strategies, but which, combined with the 'explosion in self-publishing', led to the creation of a publishing company that placed a 'pro-author' contract at its heart (Guthrie \& MacRae 2012). It is interesting to note 
that the company is a pairing of a social media strategist (MacRae) and an agent and author (Guthrie). Despite the company's disruptive practices, however, Guthrie affirmed the values that the publisher brings to the communications circuit, but also the point of keeping the role of the agent separate to that of the publisher. He does not publish any of the authors that he agents, as it would present a conflict of interest.

Due to pressures from the advent of digital technologies, as well as more general economic instabilities, the 21 st century has been a period of shrinking advances and contested royalty rates (Tivnan 2009). Literary agents have fought hard with publishers to sustain the income of traditionally published authors in an epublishing environment, and challenged publishers over ebook rights of backlist authors and literary estates. Some literary agents have made moves to exploit their authors' ebook rights themselves. In 2010, The Wylie Agency launched Odyssey Editions, a digital imprint for backlist titles from authors including Rushdie, Amis and Philip Roth. The trade press reported publishers as 'quick to condemn the move', and the ambition of Odyssey was scaled back as the agency negotiated more amenable deals for their clients with publishers (Neilan \& Page 2010). Sonia Land, the literary agent with responsibility for British saga writer Catherine Cookson's literary estate, also decided to publish ebooks directly via Amazon in 2011. Another agent was reported as seeing the announcement as "tantamount to a declaration of war" in the agent's requisitioning of the publisher's role (Land 2011, Jones \& Williams 2011). An apparent reprisal took place later in the same year, with Land's client Tom Sharpe doing a deal directly with Random House to publish some of his backlist titles as ebooks (Jones 2011). In 2010, Ian Fleming's estate took the decision to publish the James Bond ebook backlist via Ian Fleming Publications rather than with their print publisher Penguin. A deal was later negotiated with Random House for integrated print and ebook publishing in 2012 (Anon. 2012, Williams 2012).

As such, it would seem that at least some of the disruptions of digital publishing are led by agents' and publishers' financial disagreements. These disagreements threaten to disintermediate either agents or publishers, with each working directly with authors, literary estates, retailers and distributors. The disintermediated digital publishing communications circuit hence becomes a battleground for control of the marketplace, both in terms of financial reward and placement in the value chain. Relationships between authors, literary agents, publishers, retailers and distributors are changing, with the roles of some being taken over by others, or dropping out of the circuit altogether, as Figure 4 indicates by the overlapping of boxes. The formation of new partnerships is a central part of the narrative in the revised operations of 21 st century publishing.

[Insert Figure 4: Digital Publishing Communications Circuit.] 


\section{Publishers}

The publishers Blasted Heath and Guardian Books have, for the most part, direct partnerships with authors rather than via literary agents, as well as non-traditional arrangements around finance which stem from and contribute to their digital publishing models. Blasted Heath doesn't pay an advance to its authors, but instead offers what they describe as a 'very generous royalty share', paid quarterly rather than the more typical twice-yearly payment (Guthrie \& MacRae). The arrangement is thus seen as a partnership, where authors benefit substantially from each title sale. Guardian Books set up their digital publishing programme Guardian Shorts with a profit-share approach, agreeing higher-than-standard royalty rates alongside a modest advance. Although a small book publisher in terms of staffing and output (four staff; 12-26 titles a year), it draws on the brand recognition of its parent company, attracting big-name authors who are already associated with the Guardian Media Group. The company and its authors also benefits from the online platform of the Guardian website, which has an international reach and a community-focused approach: ideal for promotion within a digital environment (Montgomery \& Sidwell).

New relationships between publishers can also be observed as a result of the pressures and opportunities of the digital publishing environment. 2012 brought momentous merger news, as two of the biggest international publishing groups, Penguin and Random House (part of Pearson and Bertelsmann respectively), unexpectedly announced a merger (which negated the passage of Fleming's ebook rights from one to the other). The merger was widely perceived to be a bolstering of two already-large conglomerates against the power of Amazon, and the more general risks of the digital age (Anon. 2012). The press release formally announced the deal in corporate-speak, but nonetheless its mention of 'the long-term trends and considerable change affecting the consumer publishing industry' is indicative of a business decision pushed by external factors. Part of the 'service' offered to authors by this merger, the press release revealed, will be 'innovative self-publishing' (Pearson 2013). While it might seem oxymoronic for a publisher to offer self-publishing services, the PenguinRandom House merger would not make it the first publishing company to enter into selfpublishing territory, with Penguin USA itself already having an online self-publishing subsidiary website Book Country.

In our interviews, Guardian Books demonstrated its partnership approach with other independents, initially developing its publishing programme via distribution deals with Atlantic, A \& C Black (Bloomsbury) and Cornerstone (Random House), and in 2013 announcing a partnership with Faber \& Faber (Williams 2013). Being a small company, its print sales and distribution to retailers have been handled by other publishers, whereas its own unusual positioning as a publishing company that also has an online (but not currently 
ebook) retail site means that it sells other publishers' books. As a consequence of their own research in 2011, which revealed that 65-70\% of titles sold through the Guardian Bookshop were of hardback or non-fiction (or both), they identified themselves a becoming 'a really interesting outlet for people who are trying to sell those books that are [...] becoming harder and harder to position in bookshops', leading to them working 'closely, directly' with publishers including Faber, Random House and Penguin (Montgomery \& Sidwell).

In 2006 a loose affiliation of mid-sized independent publishers in the UK developed, grouped together as the 'Independent Alliance'. Headed by Faber, Atlantic Books, Canongate and Granta Books are also among its members. The group has, as it puts it, 'shared core values Independence, Integrity, Quality and Range - in an increasingly centralized marketplace', and gives members practical benefits such as increasing negotiating power with booksellers and suppliers (Faber \& Faber 2013a). The collaborative, partnership approaches demonstrated by our case study publishers and their wider networks are indicative of a trend identified by Thompson in Merchants of Culture with regards to outsourcing, in which an 'economy of favours' operates (Thompson, 156). However, the example of Guardian Books (however atypical, given the much bigger media group of which it is part), in its relationships with other companies, both corporate and independent, contradicts the idea that 'the world of small presses exists as a parallel universe to the world of the large corporate publishers' (Thompson, 155). Instead, a complex ecology becomes evident in which publishing companies, large, small and in between, have contrasts and similarities, and also tangible points of operational contact.

What is also evident, however, with niche publishers, independents, and larger corporates, is the importance of the development of brand, both in terms of their relationship with their customers, but also their business to business (B2B) relationships. These B2B relationships include the ways in which publishers attract authors and literary agents to work with them, and demonstrate the continuing value of their publishing services. Influenced by strong brands and a synergistic sense of 'content' provision, new entrants to the book publishing market are changing the identity of the 'publisher', as Sara Montgomery, Head of Guardian Books, identifies:

organisations like us $[\ldots]$ that have content, that aren't traditional publishers $[\ldots]$ people like TED [who] have just started a new, really interesting [...] short ebook range. The Washington Post, The New York Post, The Economist [have...] got a lot of content and they are trying to slice and dice it in different ways. These types of organisation $[\ldots]$ own the content, they're almost cutting out the author and the distributor [...] it's a relationship that goes directly between publisher and reader. (Montgomery \& Sidwell 2012) 
A range of companies who would not define themselves as book publishers actively take advantage of their intellectual property ('content'), brand identity, and community and communications networks, to publish. Here, the publisher is not cast as a gatekeeper, but rather uses its imprimatur in order to develop a brand. Others, then, begin to occupy the role of the publisher, but equally, as the next section demonstrates, publishers are also expanding their roles.

\section{Freelancers and Outsource Agencies}

Faber is something of a standard-bearer for independent publishing in the UK, given its ability to be 'fleet of foot and good opportunistically', and with its historical pedigree granting it a strong brand identity that is the envy of most publishers (Atkinson \& Blacklock 2012; Squires 2013). Their digital publishing successes with the Solar System and Waste Land iPad apps demonstrated the company's ability to develop innovative products in keeping with their brand standards. As a result, Will Atkinson, the Sales \& Marketing Director at Faber and also an Independent Publishers Guild (IPG) board member, began to receive queries from smaller publishers who were finding it difficult to navigate the new landscape. This demonstrated to Atkinson and his Faber colleagues that there was a niche for 'a comprehensive digital service aimed at independent publishers to help them participate in the ebook market' (Atkinson \& Blacklock 2012). Faber Factory was consequently founded in 2010, in order to offer digital conversion, sales, distribution and account management services to other publishers. This appropriation of a role that might otherwise have been the domain of a conversion agency was facilitated by the strength of Faber's experience as a publisher, as opposed to companies 'who speak in code and are quite faceless' (Atkinson \& Blacklock 2012).

This diversification in Faber's portfolio represents a trend in the industry, in which publishers, while still performing their primary function, also provide a suite of services that can facilitate other players in the value chain, with this potentially even overtaking their primary function of publishing. While the outsourcing of certain aspects of the publishing workflow such as copy-editing and design is nothing new, to have publishers themselves acting as an outsource agency is more unusual. Such diversification is both born of business opportunity, but also stems from an anxiety, both economic and cultural, of increasing obsolescence and irrelevance, as the self-publishing offerings promised by the Penguin/Random House merger would suggest. Faber's stake in these transactions is financial, although the relationships built through these partnerships also foster goodwill: an 
extension, in other words, of its leading role in the Independent Alliance and its B2B networks.

Faber Factory is 'powered by Constellation', the digital platform owned by the US-based Perseus Publishing Group (Faber \& Faber 2013b). This transatlantic relationship allows Faber to gain an insight into the larger and more mature American digital marketplace, and these observations trickle down to their smaller clients who cannot afford to dedicate time and money to market research. This yields its most concrete results through the Faber Factory 'dashboard', which allows publishers to see 'see where their ebooks have been distributed to, and when, and then see [...] where their titles are selling right down to title level in a specific country'. Aggregated digital sales data is reported, which the industry standard provider Nielsen Book Scan does not (Atkinson \& Blacklock 2012, Anderson 2013).

Such shifts and expansions in the role of the publisher have begun to dismantle the traditional publishing workflow, and consequently the publishing house as a cohesive corporate structure. The result is a more fragmented and atomized work culture. Fledgling companies are more likely to be built as lean start-ups, an entrepreneurial business model Eric Ries introduced on his blog in 2008 (Ries 2008, 2011). This experimentation-based iterative model went viral and is the foundation for such tech industry success stories as Dropbox, Groupon and Zappos (Greenwald 2012).Valuing a streamlined approach, such a model employs people only when a need for a certain skillset is demonstrated. And Other Stories, a small literary publisher established in 2009, exemplifies this way of working. With a staff of five, all of whom work from different international locations, the company has established a reputation for publishing critically-acclaimed international literature often neglected by larger players in the market. Recognition of this came in 2012, through a Man Booker Prize shortlisting for Deborah Levy's Swimming Home. And Other Stories operates without office space, keeping overheads to a minimum. Staff members communicate virtually, with all also operating independently as translators or in related fields. Such shifts in the publishing workforce away from hierarchical career structures and towards 'portfolio careers' is increasingly common in the publishing and media sectors (Platman et al 2005).

And Other Stories was set up as a not-for-private profit Community Interest Company (CIC). The company has altered the editorial role, by partially delegating some aspects of the choice of books to be published to their subscribers and reading groups, and crowdsourcing information about both English and foreign language titles using social media. This approach is in keeping with the lean start-up notion of creating a product that is tested before it is perfected, in order not to waste time and money. The editorial role is not the only element of the value chain that this emphasis on subscribers and external readers alters. It is also a reaction to the disappearance of highstreet bookshops, where handselling recommendations 
influences consumer book choices. Sophie Lewis, Editor-at-Large at And Other Stories, has found that social media can 'extend the traditional role of the bookseller'. The nature of their product - global literary fiction - means that 'blanket publicity speaking to the lowest common denominator' would be ineffective, whereas 'personal recommendation power' is what fuels both the company's success and publishing decisions (Lewis 2012). The company's subscription model also means that they have a channel that bypasses the monolithic power of Amazon, reflecting the shift from B2B to Director-to-Consumer (D2C) that digital technology enables.

\section{Retailers and Distributors}

Online music, film and book vendors have transformed customer expectations in the cultural industries, by offering an infinite warehouse of goods with which no bricks-and-mortar establishment can hope to compete - the much vaunted 'long tail' model that exploits millions of niche markets to shift a high volume of unique objects alongside some popular loss-leaders (Power et al 2004; Anderson 2006). In the context of the publishing industry, the internet retailer (which in the UK context is essentially Amazon), subsumes the distributor function in order to ensure the most frictionless consumer experience. Publishers were slow to create online shopfronts at the beginning of the $21^{\text {st }}$ century to sell their own books, while simultaneously being squeezed by increasingly powerful book retailers, who were in a position to dictate terms that enabled deep discounts for the consumer (Trachtenberg 2004).

The algorithmic sophistication of Amazon puts publishers' own websites at a considerable disadvantage. Patented functions such as the 'search-inside' technology, one-click purchases, and its recommendation engine also mean that Amazon is publisher-agnostic, whereas in the bricks-and-mortar environment publishers can buy exposure for new titles through display space and the production of co-promotional materials. Amazon has also led the way in disintermediating other retailers, as Wasserman has commented:

Amazon may be identified in the public mind with books, but the reality is that book sales account for a diminishing share of its overall business; the company is no longer principally a bookseller. Amazon is now an online Walmart, and while 50 percent of its revenues are derived from music, TV shows, movies and, yes, books, another 50 percent comes from a diverse array of products and services. (2012)

Amazon ploughs much of this revenue back into creating vast distribution hubs as its 'strategy hinges on getting its inventory as close as possible to as many people as possible' (Wohlsen 2013). While increased computerisation has helped many publishers streamline 
their distribution processes, the economies of scale of Amazon's operations means that they are more competitive than other online distributors dedicated to publishers.

The transformation of the book browsing and buying experience effectuated by online retail, coupled with the introduction of affordable and intuitive e-readers such as the Kindle, are key disruptive forces in book publishing. At the heart of this disruption is a characteristic which defines technology companies rather than publishers: a 'services first mentality' that bridges software and hardware in order to optimize the user experience (Bajarin 2012). This requires in-depth knowledge of the customer, and at the core of Amazon's success is the nearmonopoly it has on customer data. It builds up this knowledge from tracking all manner of interactions customers have with the site, and a multi-levelled e-commerce strategy that allows third-party sellers through its affiliate and associate programmes (Layton 2013).

Such a level of engagement is unusual in traditional book-buying, as readers have customarily been more focused on the author brand than that of the publisher. However, all the publishers we spoke to for this article demonstrated an awareness of harnessing analytics from online activity to target readers, and consequently to enhance the publisher brand and encourage customer loyalty. Such strategies can be successful when selling print books, but publishers are still at the mercy of technology companies when it comes to selling e-books, especially if they wish to benefit from Digital Rights Management (DRM) that might protect their books from piracy.

Some publishers choose to be DRM-free as part of a strategy to attract more readers. Blasted Heath commented that, 'There [are] no benefits whatsoever to DRM. All you're doing is hacking off your customers by making life that little bit more difficult'. Going DRM-free encourages customers to download books. However, as a small independent publisher, MacRae points out the advantages of using Amazon as a shopfront:

it's so much easier for people to buy a book from a bookstore that's tied to their particular bit of hardware [...] it's also better for us; if somebody sees a book on Blasted Heath, we prefer them to click through and buy it on Amazon [...] because it's another sale on Amazon, it increases its visibility, the 'also-boughts', it's better for the author, it's better for us, despite [Amazon's] cut. (MacRae \& Guthrie 2012)

\section{Readers and Devices}


In Darnton's communications circuit, readers sit at the end of a process in which the book passes from the author via various intermediaries (Figure 1). Darnton's circuit links the reader back to the author via a dotted line, but also to the 'Binder' by a double-arrowed line, indicating an $18^{\text {th }}$-century practice whereby readers would arrange for their own binding and embossing in order that books could be uniformly presented on their library shelves - the reader, in other words, as collector. For the Late 20th Century Print Publishing Communications Circuit, we removed the binder, as this practice had very largely disappeared (Figure 2). The Digital Publishing Communications Circuit (Figure 4), however, introduces the 'Device', which sits in the same place as the binder in relationship to the reader, but also has a relationship to the retailers and distributors. This relationship is strongest with the 'walled garden' generated by Amazon's Kindle, which ties in the digital reader, rendering him or her a dedicated device user and loyal consumer (Digital Book World 2012, Pogue 2012).

[Insert Figure 5: Readers in the Digital Publishing Communications Circuit.]

The mass-produced e-reader has resulted in a shift of power being wielded by intermediaries such as Amazon and Apple, as they enforce and restrict access through use of DRM, proprietary software, and - through disallowing certain kinds of content to be made available on their platforms - censorship (Anon. 2013). Despite the ease with which digital texts can be produced, their delivery can still be an expensive and time-consuming process for smaller companies, and access is restricted to those readers who can afford the appropriate device to read the content. Through their choices of reading device, readers form strong bonds with retailers and distributors. The Barnes and Noble Nook allows readers to access additional free content and wifi radio while browsing in the company's physical bookstores (Buskirk 2009). Mobile apps that cross the streams of proprietary usage - using a Kindle app on an iPad, for example - expand consumer choices. These bonds can be enforced by DRM, but can also be encouraged via social reading practices, as Kobo exemplifies.

Kobo's 'Reading Life' enables connections from the reader's account to Facebook, generates 'Reading Stats' and 'Awards' (for example, for completing a book, or reading multiple times at the same period in the day, thus 'gamifying' the reading experience). These incentivising, socially networked aspects of Kobo are indicative of a broader digital reading trend. The development of social reading sites such as Goodreads and Shelfari generate spaces in which readers can connect with each other, record their reading, and share perspectives. They are also providers of large amounts of valuable customer data, as Amazon's purchase of both companies (in 2008 and 2013 respectively) made evident (Flood 2013). As historians of reading have explored, reading has frequently been a social rather than a solitary activity (Towheed et al 2010; Rehberg Sedo 2011). The behaviours enabled by social reading sites 
are in a continuum with historical practices such as epistolary communities, reading unions and reading groups, although their digital nature makes them specific, and ripe for commercialisation. Goodreads explains its purpose as 'a free website for book lovers [....] a large library that you can wander through and see everyone's bookshelves, their reviews, and their ratings [...] post your own reviews and catalog what you have read, are currently reading, and plan to read in the future [....] join a discussion group, start a book club, contact an author, and even post your own writing' (Goodreads 2013). Websites like Goodreads, then, also create virtual reading communities, and incorporate reviewing and writing functions. They additionally power discoverability - the digital publishing holy grail - by the 20th century equivalent, word-of-mouth recommendation (Squires 2007).

Digital technologies have made significant shifts to reviewing. While traditional print and broadcast literary reviewing still exists, the rise of citizen journalism has its corollary in the books blogosphere. Digital technologies have enabled the rise of citizen literary critics such as Dove Grey Reader, who styles herself as a 'bookaholic, sock-knitting quilter who is a community nurse in her spare time'. The home-spun feel of this profile is reflected in the content and design of her website, which uses the off-the-peg blog software Typepad. As Dove Grey Reader expands:

I harbour no pretensions about being a book reviewer, let alone a literary critic, this is about sharing a subjective passion for reading with like-minded people. A lifetime's love of books and reading, a career in community nursing and a late onset degree in English Literature all underpin much of what I write, but this is all done for the love of it, unpaid and for pleasure. (Dove Grey Reader 2013)

Dove Grey Reader refutes a role as a professional literary critic, rather seeing herself as a reader connected to other readers. As such, her work might seem remote from the commercialized mechanisms of the publishing industry. Yet Dove Grey Reader's social reading environment is digital, and the reach of her blog around the world is only made possible by 21st century technologies. Moreover, because of the impact she has made in the social reading environment, Dove Grey Reader has become an influential and alternative voice, courted by publishers and making in-person appearances at literary events ranging from the Port Eliot Festival to the London Book Fair (Pack 2011). Publishers typically send key book bloggers review copies and proofs, in order to encourage discussion of the books Penguin Books UK, for example, has a Google+ 'Proof Group' (Penguin Books UK 2013). 
Although self-located as an amateur reader, due to the reach and success of her blog since its establishment in 2006, Dove Grey Reader has become part of the 'Intellectual Influences and Publicity' element of the 'Socio-Economic Conjuncture' at the centre of the communications circuit, hence influencing the movement of the book. In 'Personal Readings and Public Texts - Book Blogs and Online Writing about Literature', Steiner argues that 'Darnton can be employed to analyse and clarify the structure of the book trade and the position of the book blogs within the literary system'. Her analysis of Swedish book bloggers continues, 'nonprofessional book bloggers might be idealists, and unconnected (as a whole) to the trade, but they are still part of the book market' $(2010: 475,482)$. Such activities can confuse the line between amateur and professional readership, as the bloggers are not paid but may pick up paid work as a consequence of their online presence and, as Steiner discusses, have advertising on their websites and benefit from click-through book sales (Figure 5). As active and networked readers, they play an important role in the circulation of books, but moreover they are indicative of the reshaping of roles that occur when various agents in the communications circuit take over aspects of the functions of others.

The creation of Dove Grey Reader's community stemmed from a desire to find like-minded readers with whom to discuss books, with the discussion taking place in the 'comments' section following each of her posts. Reader-led discussions of books also occur in much more commercial environments. One of Amazon's innovations, its Customer Reviews facility, enables readers to comment on and rank purchases, using a five-star system. Bestselling titles elicit thousands of reviews, and the aggregated rankings give a very quick guide for potential purchasers of how their fellow readers rate the product.

The abuse to which Amazon's facility is open has been demonstrated multiple times, with examples of sock-puppetry - the practice of making anonymous or pseudonymous reviews either to praise your own book, or detract from those of competitors - being a regular occurrence (Vinjamuri 2012). The practice of paying for reviews - including by selfpublishing bestseller John Locke - has also been exposed (Streitfeld 2012). Falsified 'readers' demonstrate the importance of reviews to visibility on Amazon, contributing to its algorithms. As a start-up digital publisher, Blasted Heath indicated how it has paid attention to understanding Amazon's algorithms via indie author and publisher forums, in order to increase visibility, and hence sales (Guthrie \& MacRae 2012).

Aside from falsified and bulk-generated reviews, a genuine willingness to provide Customer Reviews constructs readers not solely as consumers, or as individuals who wish to share their thoughts on books, but also as part of the marketing environment of the book. Readers are thus incorporated into the digital publishing business model as co-promoters. Similar models of co-promotion can be seen in the ways readers work alongside authors, publishers and 
retailers in the social media promotion of books, by sharing, retweeting, and reposting information. Social media have given readers unprecedented and direct access to authors, via authors' online pages and feeds, and the interactions and conversations they allow.

Canongate perceives its web presence Canongate.tv as an opportunity to speak directly to 'the consumer and the public' (Cannon 2012). Job roles within Canongate are indicative of the company's approach: the marketing team when Canongate.tv launched included a Communities Manager and a Digital Content Manager. The aim of the website was to create something 'content driven', which would allow readers to 'get[...] into the worlds of our authors [...] bringing out really exclusive content that you wouldn't be able to get on Amazon and [...] constantly updating it and having that sort of fun, playful magazine feel to it so that people want to subscribe' (Cannon 2012). Cannon also discussed in interview how her role falls between editorial and sales. With the increasing importance of speaking directly to the consumer rather than using intermediaries, content and voice are crucial, either that of the publisher itself, or the platform it offers to its authors.

The creation of content for readers as part of the marketing strategy of a publishing company is turned on its head by another digital trend: that of readers creating content as 'prosumers' (Toffler 1970), a concept elaborated by Tapscott and Williams in their analysis of mass collaboration production and business models in Wikinomics (2007), and by Gomez in Print is Dead (2008). The concept is also referred to in the clever, palindromic YouTube viral hit created by Dorling Kindersley, in which a reversal of words indicates a whole new relationship with the consumer (Dorling Kindersley 2013). In the realm of publishing, consumer-based content generation is most energetic in terms of fan fiction (the eventual mainstream publishing success of the Fifty Shades of Grey trilogy demonstrated the transition from consumer to prosumer to author). The extent to which rights holders encourage or actively discourage - or even legally sanction - fan fiction demonstrates differing approaches: one which foregrounds an Intellectual Property regime, and another which fosters interaction and even co-production with consumers (Squires 2007b). Other forms of 'prosumer' activity include a range of community-based writers' websites, such as ABCTales.com and HarperCollins' Authonomy website, in which would-be authors upload and comment on others' content. Like Penguin's Book Country, and the promised Penguin/Random House self-publishing services, Authonomy provides a space for selfpublishing within conglomerate publishing, with a link-up with Authoright, a publishing and marketing services provider. Authonomy acts as a digital slushpile, encouraging readers to become involved in the publishing process as more than would-be authors:

The book world is kept alive by those who search out, digest and spread the word about the best new books - authonomy invites you to join our community, champion 
the best new writing and build a personal profile that really reflects your tastes, opinions and talent-spotting skills. (Authonomy 2013)

The kind of 'prosumer' articulated here is not only the author, but also the publisher, literary agent, reviewer, or other producing agent: crowdsourcing taste, in other words.

Publishing has seen experiments in crowdfunding. Unbound, for example, is a UK-based company concentrating on books, which operates on the model of Kickstarter or Indiegogo. The tagline, 'Books are now in your hands' has the implication that they arrive in readers' hands not via the traditional communications circuit, but via an intervention of the reader-tobe in the production process through funding their production, and with a direct link between reader and author. Although enabled by digital technologies, Unbound is aware of the historical precedent of pre-publication subscription models for publishing, citing Dickens as an example of an author who used similar methods to get published (Unbound 2013). However, Tapscott and Williams typify the 'wikinomics' approach as:

more than open source, social networking, so-called crowdsourcing, smart mobs, crowd wisdom, or other ideas that touch upon the subject. Rather, we are talking about deep changes in the structure and modus operandi of the corporation and our economy, based on new competitive principles such as openness, peering, sharing, and acting globally. (2007: 3 )

And Other Stories has built a collaborative publication model based on reading groups and 'volunteers, subscribers, interns, other kinds of supporters - expert and not-so-expert' (Lewis 2012). The reading groups are rather unusual, articulated via an online presence (initially Goodreads) and face-to-face meetings, and consisting largely of groups of translators actively working in different linguistic contexts to recommend particular titles to for publication. The model is at once open (to recommendation) and based on elite or expert taste-makers: translators are at the heart of the reading group and recommendation process, although anyone can provide publishing 'tips' via the And Other Stories website (And Other Stories 2013). Lewis describes the publisher as 'innovative in its nature because it has so many minds working in it', and the process of acquisitions is undertaken via regular, open meetings to which any mailing list member can contribute (Lewis 2012, And Other Stories 2013). And Other Stories' books can be bought via conventional and online distribution channels, but the publisher also operates by subscription. Subscribers sign up to an annual subscription, and receive benefits accordingly. The model goes beyond crowdfunding as it is more concerted and long-lasting, supporting the publisher for several titles, and - if the subscriber wishes to - 
by contributing to decisions about publication. As such, And Other Stories makes the link from the reader back to the rest of the communications circuit much more emphatic. The dotted line of Darnton's communications circuit feeding back to the author is, in And Other Stories' case, an integral part of their business model, production process, and philosophy of taste formation.

\section{Conclusion}

An examination of the various positionings, behaviours, and activities of the reader in the digital publications circuit demonstrates the radical transformations that are being enacted in the 21 st century. As Figure 5 indicates, the link between reader and publisher is becoming stronger and more two-directional, while at the same time a very strong link is forged between reader and device (and the company that operates the device). Digital technologies are affording a re-envisioned role for readers in the communications circuit, with redrawn relationships and a consequent impact on the journeys of books.

Through its analysis of publishing in the $21^{\text {st }}$ century, our redrawing of the book communications circuit demonstrates some of the radical disruptions and disintermediations that are occurring in the digital age. Traditional relationships are being short-circuited, while at the same time additional relationships are being created by new agents, or existing ones shift their roles. Throughout this redrawing, the 'Economic and Social Conjuncture' at the heart of Darnton's model retains its stable position, although the specific conditions that describe the conjuncture also shift. In the $21^{\text {st }}$ century, the contexts include how technological change enables a flouting of legal and territorial conventions, such as traditional geographical publishing markets. Piracy, and the associated - but potentially even greater - threat of a downwards price pressure on books and ebooks will be key drivers for publishing in the decades to come. Questions of content, accessibility, and both commercial and cultural value, are crucial to the shaping of the book in its passage through the communications circuit. Although patterns remain which recall the history of the printed book, the place, role and passage of the book in the digital age is undergoing very real change. It is a landscape dominated by large conglomerate publishers and, increasingly, by even larger technology companies, but it also offers space to start-ups, to independents with strong brand presence, and innovative business approaches. Our Digital Publishing Communications Circuit goes some way, we hope, to an understanding of this landscape and its agents. 


\section{References}

Alpert, D. (1987), 'Desktop Publishing: The Fourth Revolution', OCLC Systems \& Services, 3: 2, pp.21-22.

Amazon (2013), 'Welcome to Amazon's Kindle Direct Publishing',

https://kdp.amazon.com/self-publishing/signin. Accessed 20 January 2013.

Amis, M. (2000). Experience, London: Jonathan Cape.

Anderson, C. (2006), The Long Tail: Why the Future of Business is Selling Less of More, New York: Hyperion.

Anderson, S, C. (2013), 'Can Nielsen BookScan Stay Relevant In The Digital Age?', http://www.forbes.com/sites/suwcharmananderson/2013/01/07/can-nielsen-bookscan-stayrelevant-in-the-digital-age/, 7 January. Accessed 12 January 2013.

Anon. (2013), 'Apple Censorship.', http://www.huffingtonpost.com/news/apple-censorship. Accessed 6 May 2013.

Anon. (2010), 'Bond is Back on E-Books Under Estate Agreement', The Bookseller, 5 November, p.4.

Anon. (2012), 'Random House-Penguin Merger: Opinion', The Bookseller, 2 November, p.6.

And Other Stories, (2013) '11 Commandments', http://www.andotherstories.org/about/11commandments/. Accessed 25 February 2013. 
Atkinson, W. and Blacklock, S. Faber \& Faber (2012), 7 August 2012, interview.

Atwood, M. (2010), 'How I Learned to Love Twitter'. 7 April 2010.

http://www.guardian.co.uk/commentisfree/cifamerica/2010/apr/07/love-twitter-hookedfairies-garden, 7 April. Accessed 19 January 2013.

Atwood, M. (2013), https://twitter.com/MargaretAtwood. Accessed 18 June 2013.

Authonomy (2013), 'About', http://authonomy.com/about.aspx. Accessed 25 February 2013.

Bajarin, B. (2012), 'What I like about Amazon's Kindle strategy', Tech.pinions, http://techpinions.com/what-i-like-about-amazons-kindle-strategy/9951, 7 September. Accessed 6 March 2013.

Baverstock, A. (2011), The Naked Author: A Guide to Self-Publishing, London: A \& C Black.

Buskirk, E. v. (2009), 'Barnes \& Noble's Shiny, Sharing-Friendly 'Nook' eBook Reader', http://www.wired.com/business/2009/10/barnes-noble-unveils-nook-ebook-reader-again/, 20 October. Accessed 6 May 2013.

Cannon, C. Canongate (2012), 1 August, interview.

Cornford, D. and Lewis, S. (2012), Not a Gold Rush: The Taleist Self-Publishing Survey, Kindle: Taleist.

Darnton, R. (1990), 'What is the History of Books?, in The Kiss of Lamourette: Reflections in Cultural History (London: Faber \& Faber, 1990), pp.107-35. First published in Daedalus (Summer 1982), pp.65-83. 
Digital Book World (2012), 'David Pogue's Review of New Nook Points Out E-Book Walled Gardens', Digital Book World, http://www.digitalbookworld.com/2012/davidpogues-review-of-new-nook-points-out-e-book-walled-gardens/, 24 April. Accessed 19 June 2013.

Dorling Kindersley, (2013), 'The Future of Publishing', http://www.youtube.com/watch?v=Weq_sHxghcg. Accessed 6 May 2013.

Dove Grey Reader (2013), http://www.dovegreyreader.co.uk/. Accessed 24 February 2013.

Faber \& Faber (2013a). http://www.faber.co.uk/about/trade/independent-alliance/. Accessed 6 May 2013.

Faber \& Faber (2013b). http://www.faberfactory.co.uk/about-us/. Accessed 6 May 2013.

Flood, A. (2013), ‘Amazon Purchase of Goodreads Stuns Book Industry', Guardian, http://www.guardian.co.uk/books/2013/apr/02/amazon-purchase-goodreads-stuns-bookindustry, 2 April. Accessed 26 April 2013.

Gardiner, J. (2000), 'What is an Author? Contemporary Publishing Discourse and the Author Figure', Publishing Research Quarterly, 16:1, pp.63-76.

Gillies, M. A. (2007), The Professional Literary Agent in Britain, 1880-1920, Toronto: University of Toronto Press.

Gomez, J. (2008), Print is Dead: Books in Our Digital Age, London: Macmillan.

Goodreads (2013), 'How it Works', http://www.goodreads.com/about/how_it_works. Accessed 9 February 2013. 
Greenwald, T. (2012), 'Upstart Eric Ries Has the Stage and the Crowd Is Going Wild', Wired, www.wired.com/business/2012/05/ff_gururies/, 18 May. Accessed 22 June 2013.

Guthrie, A. and MacRae, K., Blasted Heath (2012), 3 August, interview.

Jones, P. (2011), 'Shut Out by Sharpe Random E-Deal', The Bookseller, http://www.thebookseller.com/news/sheil-land-shut-out-sharpe-random-edeal.html, 20 May. Accessed 20 January 2013.

Jones, P. and Williams, C. (2011), 'Agents Warn Publishers over Digital Rates', The Bookseller, 1 April, p.5.

Land, S. (2011), 'Rights and Responsibilities', The Bookseller, 1 April, p.13.

Layton, J. (2013), 'How Amazon Works', http://money.howstuffworks.com/amazon.htm. Accessed 6 March 2013.

Lewis, S., And Other Stories (2012), 1 October, interview.

Locke, J. (2011), How I Sold 1 Million eBooks in 5 Months, Longboat Key, FA.: Telemachus Press.

Montgomery, S. and Sidwell, N., Guardian Books (2012), 6 August, interview.

Moran, J. (2000), Star Authors: Literary Celebrity in America, London: Pluto Press.

Neilan, C. and Page, B. (2010), 'Battle Lines Drawn Over Digital Royalties', The Bookseller, 30 July, p.5. 
Pack, S. (2011), 'Missed Opportunities', The Bookseller 1 July, p.17.

Pearson (2012), 'Pearson and Bertelsmann agree consumer publishing partnership: Penguin and Random House to combine, creating the world's leading trade publisher', http://www.pearson.com/news/2012/october/pearson-and-bertelsmann-agree-consumerpublishing-partnership--p.html, 29 October. Accessed 20 January 2013.

Penguin Books UK (2013), 'About', https://plus.google.com/+PenguinBooksUK/about\#+PenguinBooksUK/about. Accessed 18 February 2013.

Pilkington, E. (2012), 'Amanda Hocking, the writer who made millions by self-publishing online', The Guardian, http://www.guardian.co.uk/books/2012/jan/12/amanda-hocking-selfpublishing, 12 January. Accessed 20 January 2013.

Platman, K., Salaman, G., and Storey, J. (2005), 'Living with enterprise in an enterprise economy: Freelance and contract workers in the media', Human Relations, 58: 8, pp.10331054.

Pogue, D. (2012), 'An E-Book That Glows in the Dark', New York Times, http://www.nytimes.com/2012/04/26/technology/personaltech/barnes-nobles-e-book-readerglows-in-the-dark.html?_r=0, 24 April. Accessed 19 June 2013.

Power, D., and Scott, A. J. eds. (2004), Cultural Industries and the Production of Culture, Abingdon: Routledge.

Rehberg Sedo, D., ed. (2011), Reading Communities from Salons to Cyberspace, Basingstoke: Palgrave Macmillan.

Ries, E. (2008), 'The Lean Startup', http://www.startuplessonslearned.com/2008/09/leanstartup.html, 8 September. Accessed 21 June 2013. 
Ries, E. (2011), The Lean Startup: How Constant Innovation Creates Radically Successful Businesses, London: Portfolio Penguin.

Rich, J. R. (2006), Self-Publishing for Dummies, Hoboken, NJ: Wiley Publishing.

Rushdie, S. (2012), Joseph Anton: A Memoir. London: Jonathan Cape.

Rushdie, S. (2013), https://twitter.com/SalmanRushdie. Accessed 18 June 2013.

Squires, C. (2007a), Marketing Literature: The Making of Contemporary Writing in Britain, Basingstoke: Palgrave Macmillan.

Squires, Claire, (2007b), 'The Global Market 1970-2000: Consumers', in S. Eliot and J. Rose, eds., A Companion to the History of the Book, Oxford: Blackwell Publishing, pp.406418.

Squires, C. (2013), 'Happy Birthday! Publishers' Anniversaries, Celebration, Commemoration, and Commodification', in W. Wootten and G. Donaldson, eds., Reading Penguin: A Critical Anthology, Newcastle upon Tyne: Cambridge Scholars Press, (accepted for publication June 2013), pp. 171-188.

Steiner, A. (2010), 'Personal Readings and Public Texts: Book Blogs and Online Writing about Literature', Culture Unbound 2, pp.471-494.

Streitfeld, D. (2012), 'The Best Book Reviews Money Can Buy', New York Times, http://www.nytimes.com/2012/08/26/business/book-reviewers-for-hire-meet-a-demand-foronline-raves.html?pagewanted=1\&_r=0,25 August. Accessed 18 February 2012.

Tapscott, D., and Williams, A. D. (2007), Wikinomics: How Mass Collaboration Changes Everything, London: Atlantic Books. 
Tivnan, T. (2009), 'Author Advances: It's Good for Some...', The Bookseller, http://www.thebookseller.com/feature/author-advances-its-good-some.html, 6 February. Accessed 6 May 2013.

Thompson, J. B. (2010), Merchants of Culture: The Publishing Business in the Twenty-First Century, Cambridge: Polity Press.

Toffler, A. (1970), Future Shock, London: Bodley Head.

Towheed, S., Crone, R., and Halsey, K., eds.. (2010), The History of Reading, Abingdon: Routledge.

Trachtenberg, J. (2004), 'Random House Considers Online Sales of Its Books', http://online.wsj.com/article/0,,SB110308002114100603,00.html, 15 December. Accessed 8 March 2013.

Unbound (2013), http://unbound.co.uk/about. Accessed 25 February 2013.

Vinjamuri, D. (2012), 'Do Consumer Reviews Have A Future? Why Amazon's Sock Puppet Scandal Is Bigger Than It Appears', http://www.forbes.com/sites/davidvinjamuri/2012/09/12/do-consumer-reviews-have-a-futurewhy-amazons-sock-puppet-scandal-is-bigger-than-it-appears/, 12 September. Accessed 6 May 2013.

Wasserman, S. (2012), 'The Amazon Effect', The Nation, http://www.thenation.com/article/168125/amazon-effect, 18 June. Accessed 8 March 2013.

Williams, C. (2012), 'Vintage Gets Bond Licence', The Bookseller, 16 March, pp.4-5. 
Williams, C. (2013), 'Guardian and Faber Launch Imprint', The Bookseller,

http://www.thebookseller.com/news/guardian-and-faber-launch-imprint.html, 15 April. Accessed 26 April 2013.

Wilson, J. (1995), 'The Literary Life: A Very English Story', The New Yorker, 6 March, pp.96-104.

Wohlsen, M. (2013), 'Amazon Sets Up (Really Big) Shop to Get You Your Stuff Faster', Wired, http://www.wired.com/business/2013/01/amazon-distribution-centers/,23 January. Accessed 8 March 2013. 